teachers in the use of the Internet and computers more effectively.

Based at Michigan State University, $\mathrm{H}-\mathrm{Net}$ is comprised of over 80 scholarly discussion lists spanning several disciplines. For more information on $\mathrm{H}$-Net and their activities visit the $\mathrm{H}$-Net web site at http://h-net.msu.edu.

\section{APSA and Ukrainian Academy of Political Sciences: A New Partnership}

Following contacts initiated in the Spring of 1996, the APSA has established a partnership with the Ukrainian political science community in order to facilitate the transformation of political science education in Ukraine. Mykola Mykhalchenko, President of the Ukrainian Academy of Political Sciences and Eugene K. Marchuk, former Ukrainian Prime Minister and current member of the Ukrainian Rada, visited the APSA in October to discuss principal areas of concentration.

Working through Victor Basiuk, a political scientist specializing in science and technology policy, the Association has set forward on building a series of programs designed to familiarize both parties with political institutions and academic frameworks within each country. Additional activities will include the promotion of scholarly exchanges and development of joint research projects.

Further, the Association is seeking to explore the development of a journal donation project, enabling universities in Ukraine to receive collections of books and journals, and Ukrainian participation in the Civic Education Program, an initiative led by APSA President Elinor Ostrom.

The Ukrainian Academy of Political Sciences is a voluntary public organization which unites scholars, professors of institutions of higher learning, and government officials.

\section{NSF Funds Ralph Bunche Summer Institute}

The National Science Foundation has awarded the University of Virginia $\$ 246,000$ for the Ralph Bunche Summer Institute over the next three

\author{
Minority ID Project Contributors \\ The Minority Identification Project is a collaboration of undergraduate programs and \\ graduate schools encouraging the interest of minority undergraduate students in graduate \\ study in political science. Undergraduate programs recommend promising minority graduate \\ students to APSA which, in turn, gives those names to graduate programs for recruiting \\ purposes. \\ The Minority Identification Project is ably led by Elliot Slotnick of Ohio State University. The \\ Association thanks all those who made contributions.

\begin{tabular}{|c|c|}
\hline \multicolumn{2}{|l|}{ Departmental Contributions } \\
\hline Duke University & University of Iowa \\
\hline Emory University & University of Chicago \\
\hline Harvard University & University of Colorado, Boulder \\
\hline Indiana University & University of Illinois, Urbana-Champaign \\
\hline Massachusetts Institute of Technology & University of Massachusetts, Amherst \\
\hline Miami University & University of Minnesota \\
\hline Ohio State University & University of North Carolina, Chapel Hill \\
\hline Princeton University & University of Pennsylvania \\
\hline Rutgers University & University of Rochester \\
\hline Stanford University & University of Texas at Austin \\
\hline Syracuse University & University of Virginia \\
\hline University of California, Berkeley & University of Wisconsin, Madison \\
\hline University of California, Los Angeles & Washington University \\
\hline University of California, San Diego & Yale University \\
\hline \multicolumn{2}{|l|}{ Individual Contributions } \\
\hline \multicolumn{2}{|l|}{ Ronald Brown, Wayne State Univesity } \\
\hline \multicolumn{2}{|c|}{ Henry Brady, University of California-Berkeley } \\
\hline \multicolumn{2}{|c|}{ Lavonna Blair, University of Southern California } \\
\hline \multicolumn{2}{|l|}{ William Corlett, Bates College } \\
\hline \multicolumn{2}{|l|}{ Cynthia Enloe, Clark University } \\
\hline \multicolumn{2}{|c|}{ Charles A. Johnson, Texas A\&M University } \\
\hline \multicolumn{2}{|c|}{ William R. Keech, University of North Carolina } \\
\hline \multicolumn{2}{|l|}{ Stanley Kelley, Jr., Princeton University } \\
\hline \multicolumn{2}{|c|}{ Donald Matthewson, University of California-Riverside } \\
\hline \multicolumn{2}{|c|}{ Dianne Pinderhughes, University of Illinois at Urbana-Champaign } \\
\hline \multicolumn{2}{|c|}{ David Plotke, New School for Social Research } \\
\hline \multirow{2}{*}{\multicolumn{2}{|c|}{ Wilbur Rich, Wellesley College }} \\
\hline & Sage Publications, Inc. \\
\hline \multicolumn{2}{|l|}{ John Sprague, Washington University } \\
\hline \multicolumn{2}{|l|}{ Elliot Slotnick, Ohio State University, } \\
\hline \multicolumn{2}{|l|}{ Ross B. Talbot, Iowa State University } \\
\hline \multicolumn{2}{|l|}{ Hanes Walton Jr., University of Michigan } \\
\hline \multicolumn{2}{|l|}{ Jennifer Widner, University of Michigan } \\
\hline David Wilsford, Institute for American & es, France \\
\hline
\end{tabular}

years. Coupled with funds from APSA and the University of Virginia, 15 students will be hosted at the Institute in Charlottesville, Virginia each year for the next three years. In addition, under the terms of the grant, the students' stipend will be doubled.

Designed to introduce AfricanAmerican students, selected in a national competition, to the world of graduate study and encourage application to Ph.D. programs in political science, the Ralph Bunche Summer Institute is a five-week program consisting of two graduate-level courses, guest lectures from leading political scientists, a recruitment day attended by recruiters from Ph.D. programs, and a special program in preparation for taking the Graduate Record Ex- amination. Steven Finkel of the University of Virginia and Avon Drake of Virginia Commonwealth University taught at the Institute hosted by the University of Virginia in 1996.

The Institute is being funded through the Research Experiences for Undergraduates Program, the Political Science Program, and an ethics program at NSF. Paula D. McClain, Chair of the Department of Government at UVA, has led the effort to obtain funding from NSF and wrote the grant proposal. Frank Scioli and Bonney Sheahan are the NSF program officers for this grant.

Hosted in past years by Southern University, Louisiana State University, Spelman College, Emory University, Morehouse College, Georgia State University, and Clark Atlanta 